\title{
The change management in an academic institution: An organizational perspective
}

\author{
Marilou A. Maderazo* \\ Higher Colleges of Technology, Ras Al Khaimah, UAE
}

\author{
Key Words \\ Change \\ Change management \\ Awareness \\ Organizational change \\ Capability \\ Contribution to organizational \\ change
}

Received: 9 July 2016

Accepted: 5 September 2016

Published: 19 December 2016

\begin{abstract}
The researcher has conducted this study to assess the change management in Bahrain Training Institute, an academic institution that exists in the Kingdom of Bahrain. This is a government organization that contributes to the skills development of the national workforce in the country. The institute experienced some changes due to the transfer of its supervision from the Ministry of Labor to the Ministry of Education. Being a quasi-independent training institution under the Ministry of Labor to being a centralized institution based on the memorandum of Civil Service Bureau has brought some changes, mostly in the administrative aspect. The problem encountered is that both the academic and non-academic staff employees experience changes that positively and negatively affect their motivation, thus affecting the organizational outcomes. This paper applied the Prosci ADKAR Model to assess the organization's status and level of effectiveness in terms of its awareness, capability, and contribution to change. This study used the descriptive design and came up with a questionnaire and interview to gather data. This leads to encouraging trainers and other employees to embrace change for the benefit of all; improve the current practice of change management in the institute; conduct training and meetings, and communicate plans among each member of the organization. The output of this study will help the trainees cope with changes resulting in participation, thus achieving one common objective. Furthermore, this will help the top management realize that employee productivity increases when they feel supported.
\end{abstract}

(C2016 The Author(s). Published by TAF Publishing.

\section{INTRODUCTION}

The Change Management in an Academic Institution: An Organizational Perspective Change happens everywhere, the pace of change is getting faster, and everyone is affected by it. Disruptive technology advances, new competitive environments, pressure from financial markets, government regulations and globalization are factors that direct the everincreasing rates of change by organizations in many industries in different countries. All these factors demand responses from today's organization. According to Newstrom (2011), any modification that happens in the workplace which somehow affects the action of employees is known as change.

Change is very necessary but transforming the organization requires effort. Regardless of the wholehearted support, available resources and truthful intentions, efforts to change fail. The mistakes can be found most often on the process of implementation (Spector, 2013). How change is managed and implemented are where the barriers exist. Prosci (2016), well-known leader in change management research, defined change management as the use of processes and tools which are prepared in order that individuals or groups will cope up from present to upcoming condition, like when targeted result is achieved.

\footnotetext{
${ }^{*}$ Corresponding author: Marilou A. Maderazo

†Email: malou.maderazo@hct.ac.ae
} 
If change management happened, people are now involved in the process of change and together they work.

Bahrain Training Institute, an academic institution existing in the Kingdom of Bahrain which contributes to the skills development of the national workforce in the country, has experienced some organizational changes. This was due to the transfer of its supervision from Ministry of Labor to Ministry of Education. Being a quasi-independent training institution under the Ministry of Labor to being a centralized institution based on the memorandum of Civil Service Bureau has brought some changes mostly in the administrative aspect. These changes have brought problems in both the academic and non-academic staff employees who experienced changes thus affecting their motivation both positively and negatively.

This study aimed at assessing the change management in Bahrain Training Institute. Specifically this study sought to answer on the status and level of effectiveness of the change management implemented in Bahrain Training Institute in terms of its awareness, capability, and contribution for change.

The output of this study is significant among the trainers which will help in coping up with changes thus attaining employee participation which will lead towards the achievement of one common objective. This will give insights to the top management to focus their attention on developing programs which can help both academic and non-academic staff cope with changing conditions.

\section{LITERATURE REVIEW}

With regard to previous studies, this research study differs as it emphasizes that change is vital and a constant feature in any organization. Organizations are subject to continuous change and cannot be escaped in both social and organizational life.

Schermerhorn (2010) stated that organizations that have an effective change management consider change itself as the motivating power which leads to growth and success in the future. Change is considered as an opportunity to improve productivity, thus success for an organization. The content of the present research resembles here in terms of the findings.

Kreitner and Angelo (2009) Silahtaroglu and Pelin (2016) discussed that the different forces which came from outside organization need to be focused on. These pressures which affect globally will determine how essential the organization is in coping up with changes depending on the kind of business and the services and products they are into. Similarly, Wilson (2014) explained that bringing change in the organization is the most challenging problem. As products undergo changes, the more change in organization is needed. The concept is different from the present study since it tackled change management in terms of products.

However, Palmer et al. (2009) discussed that organizations are different from each other because managers have different responses to several pressures outside. Few managers may resist, some will respond moderately; some will not recognize them as threat while other managers do. Hitt et al. (2011) agrees that in order to survive, organizations must consider both the inside and outside forces for change. These concepts are similar to the study in terms of how the respondents react to the previous changes.

Moreover, Attong (2013) and Rijal (2016) stated that managing change has something to do with the fear of the stakeholders to face the impact of changes towards the future improvement of the process. Likewise, Karten (2009) stated that any change would be easier to do when we give our old systems towards new state which are not interrupted by any 
terms of content and recommendations.

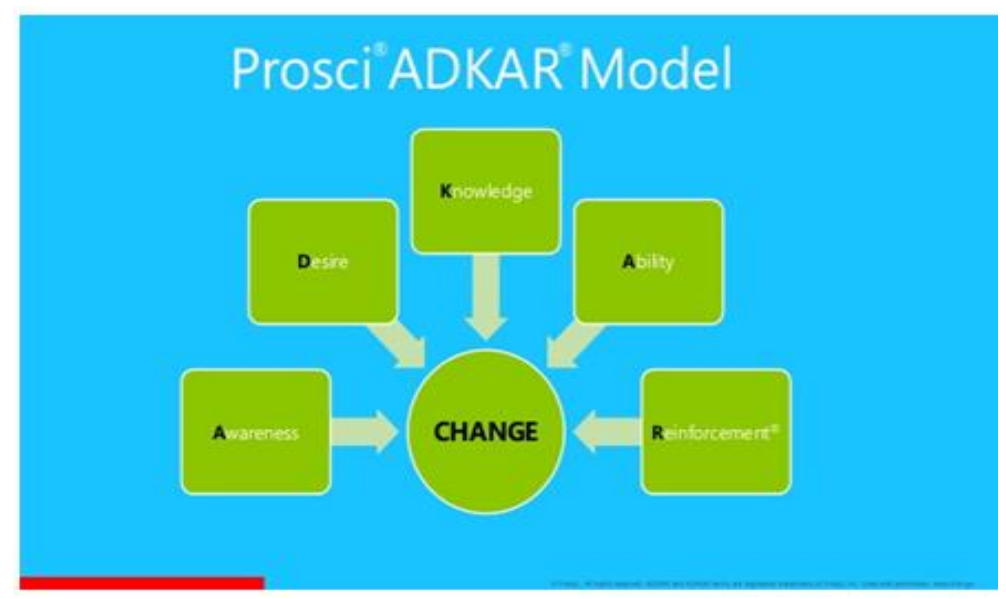

FIGURE 1. Theoretical Framework of the Study ADKAR ® Change Management Model (PROSCI, 1999)

\section{METHODOLOGY}

This chapter highlights various research methods and tools used in this study which are relevant to the research work. It explores relevant aspects to the materials and methods used in this paper such as methodology, tools for data gathering, methods for collecting data and data analysis.

\section{Design of the Research}

In this study, the descriptive research method was employed so as to assess the level of effectiveness of change management process in an academic institution: Bahrain Training Institute Perspective in terms of awareness for organizational change and development; capability to acknowledge organizational change; contribution to organizational change. The researcher used the research method for the purpose of coming up with some firsthand data from among the trainers of BTI who are the main respondents of the study.

\section{Respondent of the Study}

The study used the purposive sampling which includes administrators, non-academic and academic staff with at least three years of work experience in the training institute as the respondents of study. Among the respondents are ten (10) administrators who were chosen on the degree of their involvement in the change management process such as human resource officer, the finance officer and the different heads of departments. Fifty (50) trainers or the academic staff from among the different departments will also be among respondents. This group is the one that has been in the institution during the administration of Ministry of Labor. Another group of respondents are members of non-academic staff who were chosen also based on the criteria for academic staff. Basically, these groups of respondents are those who were members of the institution during the time it was handled by the Ministry of Labor and currently by the Ministry of Education.

\section{Research Instrument}

Questionnaires were used for the respondents which consisted of four parts: The first part assessed the status of the practices of change management in Bahrain Training Institute 
TABLE 1

Respondents of the Study

\begin{tabular}{lcc}
\hline \hline Characteristics & Selected Respondents & Percentage \\
\hline Administrators & 10 & $10 \%$ \\
Academic Staff & 50 & $60 \%$ \\
Non-academic Staff & 20 & $33 \%$ \\
Total & 80 & $100 \%$ \\
\hline \hline
\end{tabular}

in terms of awareness for organizational change and development; capability to acknowledge organizational change; contribution to organizational change. The second part quantified was the level of effectiveness of the practices of change management in the training institute. The third part identified the problems encountered in the organizational stress management. The fourth part is the recommendation that might be offered to improve the change management.

Personal interviews were conducted to support the data gathered by the survey questionnaire. Below is the Likert scale which will be used to assess the status of the practices of change management in the Bahrain Training Institute:

TABLE 2

Likert scale description

\begin{tabular}{|c|c|c|c|}
\hline Scale & Range & Interpretation & Description \\
\hline 5 & $4.50-5.0$ & Always Implemented & $\begin{array}{l}\text { The change management in Bahrain Training } \\
\text { Institute has always implemented. }\end{array}$ \\
\hline 4 & $3.50-4.49$ & Usually Implemented & $\begin{array}{l}\text { The change management in Bahrain Training } \\
\text { Institute has always implemented. }\end{array}$ \\
\hline 3 & $2.50-3.49$ & Sometimes Implemented & $\begin{array}{l}\text { The change management in Bahrain Training } \\
\text { Institute has always implemented. }\end{array}$ \\
\hline 2 & $1.50-2.49$ & Rarely Implemented & $\begin{array}{l}\text { The change management in Bahrain Training } \\
\text { Institute has always implemented. }\end{array}$ \\
\hline 1 & $1.00-1.49$ & Never Implemented & $\begin{array}{l}\text { The change management in Bahrain Training } \\
\text { Institute has always implemented. }\end{array}$ \\
\hline
\end{tabular}

The table below was the Likert Scale used as instrument to measure the level of effectiveness of change management in Bahrain Training Institute:

TABLE 3

Level of effectiveness of change management

\begin{tabular}{llll}
\hline \hline Scale & Mean & Interpretation & Description \\
\hline 5 & $4.50-5.00$ & Very Effective & The change management in Bahrain Training Institute is very effective \\
4 & $3.50-4.49$ & Effective & The change management in Bahrain Training Institute is effective \\
3 & $2.50-3.49$ & Neither & The change management in Bahrain Training Institute is neither effective \\
2 & $1.50-2.49$ & Ineffective & The change management in Bahrain Training Institute is ineffective \\
1 & $1.00-1.49$ & Very Ineffective & The change management in Bahrain Training Institute is very ineffective \\
\hline \hline
\end{tabular}




\section{Validation of Instruments}

To validate the instrument, a sample of questionnaires was distributed among the colleagues. The rationale for validating the instrument is to establish its reliability and validity, avoid ambiguous items and biased statements. Comments made were considered by the researcher for the final draft. There is a dry-run among the group who are not respondents for the purpose of ensuring the questionnaires as instruments of collecting data. A pilot study was undertaken among faculty members of the training institute who acted as subjects of the study. This was done to ensure the validity of data and to make sure that the respondents are capable of providing the required information. Experts have provided comments and suggestions which make the research instrument valid. Words stated in the questionnaire that are unclear are modified.

\section{Data Gathering Procedure}

The questionnaire was distributed among the administrators, academic and non-academic staff of Bahrain Training Institute. The target group was familiar with the issues and questions included in the questionnaire and had experienced the change that took place in the organization. This has provided the researcher the chance to meet them personally and conduct observations.

\section{Data Processing and Statistical Treatment}

The data were gathered and analyzed using the statistical techniques of Excel. In the status of change management, respondents' rating was analyzed using the weighted mean average with regard to the practices based on awareness for the necessity to change, desire to sustain and contribute to change. Similar procedure was used in analyzing the level of effectiveness. The t-test was used to analyze and process the significant difference of the respondents' perception on the implementation of change management.

\section{RESULTS}

TABLE 4

Status of managing change in Bahrain training institute in terms of awareness to organizational change

\begin{tabular}{|c|c|c|c|c|c|}
\hline Indicators & Trainers & Non-Academic Staff & Officers Composite & Mean & Interpretation \\
\hline $\begin{array}{l}\text { Employee is knowledgeable } \\
\text { about the future development } \\
\text { of the institution }\end{array}$ & 2.20 & 3.53 & 3.20 & 2.98 & Moderately Agree \\
\hline $\begin{array}{l}\text { Employee is aware of the acad- } \\
\text { emic issues within the institution }\end{array}$ & 2.90 & 3.53 & 3.20 & 3.21 & MA \\
\hline $\begin{array}{l}\text { Information about the institution- } \\
\text { al development is coming from the } \\
\text { top management }\end{array}$ & 2.20 & 3.47 & 4.00 & 3.22 & MA \\
\hline $\begin{array}{l}\text { Information of the changes is consi- } \\
\text { stent }\end{array}$ & 2.13 & 3.53 & 3.60 & 3.09 & MA \\
\hline $\begin{array}{l}\text { Majority of the changes in the policy } \\
\text { are acknowledged by the employees }\end{array}$ & 3.93 & 2.47 & 3.40 & 3.27 & MA \\
\hline Weighted Mean & 2.68 & 3.31 & 3.48 & 3.15 & Moderately Agree \\
\hline
\end{tabular}

The table above presents the perception of the respondents on the status of managing 
development with a total mean of 3.15, i.e. they moderately agree. The findings signify that the employees of BTI somehow are aware of the changes that would possibly happen.

TABLE 5

Status of managing change of Bahrain training institute in terms of capability to acknowledge organizational change

\begin{tabular}{llllll}
\hline \hline Indicators & Trainers & Non-academic Staff & Officers & Composite Mean & Interpretation \\
\hline $\begin{array}{l}\text { There are no psychological blocks } \\
\text { in accepting the changes }\end{array}$ & 3.80 & 3.47 & 2.40 & 3.22 & MA \\
$\begin{array}{l}\text { The employees are capable physic- } \\
\text { ally to adapt to changes }\end{array}$ & 3.87 & 3.07 & 3.60 & 3.51 & $\mathrm{~A}$ \\
$\begin{array}{l}\text { There is enough time to build up } \\
\text { the required skills }\end{array}$ & 4.47 & 3.33 & 3.40 & 3.73 & $\mathrm{~A}$ \\
$\begin{array}{l}\text { Resources are sufficient to sustain } \\
\text { the progress of latest abilities }\end{array}$ & 3.83 & 3.33 & 3.40 & 3.52 & $\mathrm{~A}$ \\
$\begin{array}{l}\text { Employees have enough Intellectual } \\
\text { capability to adapt to changes }\end{array}$ & 3.00 & 3.47 & 3.40 & 3.29 & MA \\
\begin{tabular}{l} 
Weighted Mean \\
\hline \hline
\end{tabular} & 3.80 & 3.33 & 3.24 & 3.46 & Moderately Agree \\
\hline
\end{tabular}

The table above shows that the respondents moderately agree on the status of managing change in terms of capability to acknowledge organizational change with a weighted mean of 3.46 which means that the respondents have a common perception on the status of managing change in BTI since their perception falls under the same category when they are interpreted verbally. The result implies that the institution is quite capable of acknowledging change.

TABLE 6

Status of managing change in Bahrain training institute in terms of contribution to organizational change

\begin{tabular}{llllll}
\hline \hline & Trainers & Non-academic Staff & Officers & Composite Mean & Interpretation \\
\hline $\begin{array}{l}\text { The reinforcement of } \\
\text { change is meaningful }\end{array}$ & 4.53 & 3.47 & 3.60 & 3.87 & $\mathrm{~A}$ \\
$\begin{array}{l}\text { There is accomplishm- } \\
\text { ent achieved in the cha- } \\
\text { nges that took place }\end{array}$ & 2.93 & 3.53 & 3.60 & 3.35 & $\mathrm{MA}$ \\
$\begin{array}{l}\text { There is positive impact } \\
\text { of the changes made }\end{array}$ & 3.87 & 3.67 & 3.20 & 3.58 & $\mathrm{~A}$ \\
$\begin{array}{l}\text { The management is supp- } \\
\text { ortive of the new system }\end{array}$ & 3.53 & 3.60 & 3.80 & 3.64 & $\mathrm{~A}$ \\
$\begin{array}{l}\text { There is system in place to } \\
\text { reinforce the change }\end{array}$ & 2.5 & 3.33 & 3.60 & 3.14 & $\mathrm{MA}$ \\
\begin{tabular}{l} 
Weighted Mean \\
\hline \hline
\end{tabular} & 3.47 & 3.52 & 3.56 & 3.52 & Agree \\
\hline
\end{tabular}

The table 6 presents the status of managing change in terms of contribution to organizational change with an average overall perception of Agree or 3.52. Shermerhorn (2010) stated that change is considered as an opportunity to improve productivity, thus success for an organization.

The table 7 shows that the respondents viewed the indicator at similar level which 
means that the training institute is neither effective nor ineffective in performing its change management with an average of 3.08 which is Neither Effective or Ineffective when verbally interpreted. The result also indicates that the training institute is moderate in its effectiveness in terms of knowledge of employees about its future development; awareness of academic issues particularly where the information is coming from and its consistency; and the acknowledgement of the employees on the major changes to happen.

TABLE 7

Level of effectiveness of managing change in Bahrain training institute in terms of awareness for organizational change and development

\begin{tabular}{|c|c|c|c|c|c|}
\hline Indicators & Trainers & Non-academic Staff & Officers & Composite Mean & Interpretation \\
\hline $\begin{array}{l}\text { The employee is knowledgeable about } \\
\text { the future development of the institution }\end{array}$ & 1.53 & 3.07 & 3.40 & 2.67 & $\mathrm{~N}$ \\
\hline $\begin{array}{l}\text { The employee is aware of the academic iss- } \\
\text { ues within the institution }\end{array}$ & 1.57 & 3.53 & 3.60 & 2.90 & $\mathrm{~N}$ \\
\hline $\begin{array}{l}\text { The information about the institutional de- } \\
\text { velopment is coming from the top manage- } \\
\text { ment }\end{array}$ & 3.00 & 3.00 & 3.60 & 3 & $\mathrm{~N}$ \\
\hline Information of the changes is consistent & 2.97 & 3.20 & 3.75 & 3.31 & $\mathrm{~N}$ \\
\hline $\begin{array}{l}\text { Majority of the changes in the policy are ac } \\
\text { knowledged by the employees }\end{array}$ & 3.17 & 3.33 & 3.5 & 3.33 & $\mathrm{~N}$ \\
\hline Weighted Mean & 2.45 & 3.23 & 3.57 & 3.08 & Neither \\
\hline
\end{tabular}

TABLE 8

Level of effectiveness of managing change in Bahrain training institute in terms of capability to acknowledge to organizational change

\begin{tabular}{|c|c|c|c|c|c|}
\hline Indicators & Trainers & "Non-academic Staff & Officers & "Composite Mean & Interpretation \\
\hline $\begin{array}{l}\text { There a no psychological blocks } \\
\text { in accepting the changes }\end{array}$ & 3.57 & 3.07 & 3.00 & $3.217 \mathrm{~N}$ & \\
\hline $\begin{array}{l}\text { The employees are capable phys- } \\
\text { ically to adapt to changes }\end{array}$ & 4.13 & 3.33 & 3.00 & 3.49 & $\mathrm{~N}$ \\
\hline $\begin{array}{l}\text { There is enough time available to } \\
\text { develop the needed skills }\end{array}$ & 2.90 & 3.53 & 3.60 & 3.34 & $\mathrm{~N}$ \\
\hline $\begin{array}{l}\text { Resources are sufficient to support } \\
\text { the development of new abilities }\end{array}$ & 3.70 & 3.47 & 2.80 & 3.32 & $\mathrm{~N}$ \\
\hline $\begin{array}{l}\text { The employees have enough Inte- } \\
\text { llectual capability to adapt to changes }\end{array}$ & 3.37 & 3.27 & 2.80 & 3.15 & $\mathrm{~N}$ \\
\hline Weighted Mean & 3.53 & 3.33 & 3.04 & 3.30 & Neither \\
\hline
\end{tabular}

The table 8 presents the level of effectiveness of managing change in Bahrain Training Institute in terms of its capability to acknowledge organizational change. It shows that the practice of managing change is neither effective nor ineffective in the training institute with the mean average of 3.30. It further shows that all the sub-indicators cited in this study are all viewed as neither. Since the result shows that managing change is neither effective nor ineffective in terms of its capability, it revealed that the employees of training institute are somehow capable to accept the changes that are being implemented from previous administration to the new one. 
of contribution to organization is effective which got a mean average of 3.52 which means that the training institute is practicing the change management effectively. They found that the reinforcement of change is meaningful having an accomplishment in the changes that took place.

TABLE 9

Level of effectiveness of managing change in Bahrain training institute in terms of contribution to organizational change

\begin{tabular}{|c|c|c|c|c|c|}
\hline Indicators & Trainers & Non-academic Staff & Officers & Composite Mean & Interpretation \\
\hline $\begin{array}{l}\text { The reinforcement of change } \\
\text { is meaningful }\end{array}$ & 3.93 & 3.33 & 3.60 & 3.62 & $\mathrm{E}$ \\
\hline $\begin{array}{l}\text { There is accomplishment ac- } \\
\text { hieved in the changes that took place }\end{array}$ & 4.17 & 3.67 & 3.20 & 3.68 & E \\
\hline $\begin{array}{l}\text { There is positive impact of } \\
\text { the changes made }\end{array}$ & 3.90 & 3.40 & 3.40 & 3.57 & E \\
\hline $\begin{array}{l}\text { The management is suppor- } \\
\text { tive of the new system }\end{array}$ & 4.10 & 3.53 & 3.40 & 3.68 & E \\
\hline $\begin{array}{l}\text { There is system in place to } \\
\text { reinforce the change }\end{array}$ & 2.13 & 3.60 & 3.40 & 3.04 & $\mathrm{~N}$ \\
\hline Average & 3.65 & 3.51 & 3.40 & 3.52 & $\mathrm{E}$ \\
\hline
\end{tabular}

TABLE 10

Problems encountered in managing change in Bahrain training institute

\begin{tabular}{llll}
\hline \hline No. & Problems Encountered & Freq & Rank \\
1 & Organization is stiff and bureaucratic & 35 & 1 \\
2 & There is employee resistance & 33 & 2 \\
3 & Emotional barriers among employees exist & 28 & 3 \\
4 & Cognitive barriers exist & 25 & 4 \\
5 & There are cultural barriers & 22 & 5 \\
6 & Employees cannot overcome the old tradition & 19 & 6 \\
7 & Methods of implementation are applied wrongly & 18 & 7 \\
8 & There is inadequate plan for the change & 15 & 8 \\
9 & Lack of support from the management & 12 & 9 \\
10 & There is lack of trainings and seminars on the changes to be imposed & 5 & 10 \\
\hline \hline
\end{tabular}

The table presents the problems encountered by the respondents in the change management system of Bahrain Training Institute which are mostly due to the nature of the organization which is stiff and bureaucratic, the employee resistance" and the emotional barriers which exist among employees. Categorically, the result in the table would serve as a guide towards improved change management process of the current system being an effective mechanism in extending the change management of the Bahrain Training Institute among its shareholders.

\section{CONCUSION AND DISCUSSION}

In the light of this research, there were several findings that are very important to understand organizational change in the respective research subject. Based on the findings, this study has concluded some ideas which are relevant and these findings are the bases of writing some recommendations which might be useful to Bahrain Training Institute. 


\section{Findings}

1. On the status of change management in terms of awareness for organizational change and development, the respondents moderately agree that employees are aware of the future development of the institution.

2. On the status of change management in terms of capability for organizational change and development, the respondents moderately agree that employees are capable to cope with changes

3. On the status of change management in terms of contribution for organizational change, the respondents agree that the management is supportive of the new system.

4. On the level of effectiveness of change management in terms of awareness for organizational change and development, the respondents rated "neither" that the employees are aware of the academic issues since the information is consistent.

5. On the level of effectiveness of change management in terms of capability to acknowledge organizational change, the respondents rated "neither" that the employees are capable to adapt physically and intellectually.

6. On the level of effectiveness of change management in terms of contributions for organizational change, the respondents rated "effective" that there is positive impact of changes made. There is also system in place to reinforce the change.

7. There are three major problems encountered in the implementation of change management which are the following: First : Organization is stiff and bureaucratic;

Second: There is employee resistance; Third: Emotional barriers among employees exist.

\section{Conclusion}

1. Responses have shown that knowledge of employees about the future development of the institution has been linked to the reason why they responded 'moderately agree'. In addition, Information of the changes has to be consistent as they responded the same under these findings.

2. The respondents moderately agree on the status of managing change in terms of capability to acknowledge organizational change since their perception falls under the same category when they are interpreted verbally. The result implies that the institution is quite capable of acknowledging change.

3. The status of managing change in terms of contribution to organizational change gained an average overall perception of Agree. This implies that every change becomes welcomed as an opportunity for increasing efficiency and building new organizational success.

4. Change management system in Bahrain Training Institute is neither effective nor ineffective as rated by the respondents.

5. Change management system in Bahrain Training Institute is neither effective nor ineffective as rated by the respondents.

6. Change management system in Bahrain Training Institute is neither effective nor ineffective as rated by the respondents.

7. The problems encountered by the respondents in the change management system of Bahrain Training Institute are mostly due to the nature of the organization which is stiff and bureaucratic, the "employee resistance" and the emotional barriers which exist among employees as shown on the ranking of certain problems encountered by the institution.

\section{Significance of the Study}

This study is significant among the different beneficiaries. First, the output particularly helped the trainers to cope up with changes and not resist them. Trainers who believed that they are involved in the practice of change can together work towards the achievement 
of one common objective. The findings gave insights to the administrators that employee performance increases when they feel supported.

Second, the Human Resource Department can focus their attention on developing programs that help both academic and non-academic staff cope with changing conditions. It is therefore important for the HRD personnel to find ways on how people will embrace change. Third, the study could be helpful to neophyte researchers for future reference specifically in the field of business. Finally, this study will be a springboard for future research. Replication of the study will help validate the findings of the current study.

\section{LIMITATIONS AND RECOMMENDATIONS}

Respondents of the study are the heads of department, trainers, and students of the institute. Thus, the findings are applicable only to the subjects of the investigation and do not represent the perceptions of the non-academic staff of the institution. The area of study is only the Bahrain Training Institute which is located at Isa Town, Kingdom of Bahrain.

1. The employees have to be communicated about the development plan of the institution. Full participation of the employees has to be encouraged in order for them to be aware of the progress of the institution.

2. The institution has to continually acknowledge employees' positive response to changes instituted in the organization. The response of the employees should be directly credited on some non-monetary reward to maintain employees' behavior.

3. A continued response in this aspect is being recommended to the management. The organization has somehow instituted a good mechanism in giving support to the employees which has impacted to organizational success during the process of any organizational changes.

4. Communicate the plans to each member of the organization.

5. Conduct trainings and meetings on the changes to be imposed in the organization.

6. A continued response in this aspect is being recommended to the management. The organization has somehow instituted a good mechanism in giving support to the employees which has impacted to organizational success during the process of any organizational changes.

7. Categorically, the result in the table would serve as a guide towards improved change management process of the current system being an effective mechanism in extending the change management of the Bahrain Training Institute among its shareholders.

\section{REFERENCES}

PROSCI. 1999. ADKAR®Change management model. URL: goo.gl/Ot8Bw4 (accessed October 14, 2016).

Attong, Maxine, and Terrence Metz. 2013. Change or die: The business process improvement manual. New York, NY: CRC Press.

Hitt, Michael A., Adrienne Colella, Chet Miller, C. 2011. Organizational behavior. New Jersey, NJ: John Wiley \& Sons Inc. Karten, Naomi. 2009. Changing how you manage and communicate change: Focusing on the human side of change. London, UK: IT Governance Publishing.

Kreitner, Robert and Angelo Kinicki. 2010. Organizational behavior, 538-545. New York, NY: McGraw-Hill. Newstrom John W. 2011. Organizational behavior: Human bahevior at Work. New York, NY: McGraw-Hill. Palmer, Ian, Richard Dunford, and Gib Akin. 2009. Managing Organizational Change. New York, McGraw-Hill.

PROSCI. 2016. What is change management? URL: goo.gl/8qAsjF (accessed October 14, 2016).

Rijal, Sapna. 2016. The influence of transformational leadership and organizational culture on learning organization: A comparative analysis of the IT sector. Thailand. Journal of Administrative and Business Studies 2, no. 3: 121-129. 
DOI: 10.20474 /jabs-2.3.3

Schermerhorn, John R. 2010. Organizational behavior, 11th ed. New York, NY: Prentice Hall. Spector, Bert. 2013. Implementing organizational change: Theory into practice. New York, NY: Pearson.

Silahtaroglu, Gokan, and Pelin Vardarlier . 2016. Leaders impact on organizational behavior: A text mining study on universities in turkey. International Journal of Business and Administrative Studies 2, no. 2: 73-77.

DOI: $10.20469 /$ ijbas.2.10005-2

— This article does not have any appendix. - 